\title{
DETECTION OF TRANSGENIC EVENTS IN MAIZE USING IMMUNOCHROMATOGRAPHIC STRIP TEST AND CONVENTIONAL PCR
}

\author{
Detecção de eventos transgênicos em milho utilizando tiras \\ imunocromatográficas e PCR convencional
}

\author{
Narjara Fonseca Cantelmo ${ }^{1}$, Édila Vilela de Resende Von Pinho ${ }^{2}$, Renzo Garcia Von Pinho ${ }^{2}$, \\ Iolanda Vilela Von Pinho ${ }^{3}$, Micaela Sandim Nascimento ${ }^{3}$
}

\begin{abstract}
With the growth in the transgenic market, fast and economically viable methodologies are necessary for undertaking transgene detection tests, both for identification of contamination in seeds and in grain. Seeds from commercial conventional GNZ 2004, and transgenic VT-Pro (MON89034), Roundup Ready (NK603) and Herculex (TC1507) maize cultivars were used. In order to simulate different levels of contamination, the transgenic seeds were mixed with conventional seeds at levels of $0.2 \%$, $0.4 \%, 1.0 \%$ and $1.6 \%$ for VT-Pro, and $0.2 \%, 0.5 \%, 0.8 \%$ and $1.2 \%$ for Roundup Ready and Herculex. The lateral flow membrane strip test was performed in the whole seed, endosperm and embryo. For evaluation of the specificity of the technique in detection of the TC1507 event by means of the conventional PCR technique, seeds of the commercial maize hybrid GNZ 2004 were used as negative control, and the maize hybrid $2 \mathrm{~B} 655 \mathrm{Hx}$ as positive control. In order to simulate different levels of contamination, transgenic seeds were mixed with conventional seeds at the levels of $10 \%, 5 \%, 1 \%, 0.5 \%$ and $0.1 \%$. Seeds from each sample were crushed, and then DNA extraction was performed by the CTAB $2 \%$ method. Using the immunochromatographic strip, it was possible to evaluate the expression of proteins related to the VT-Pro, Roundup Ready and Herculex events when whole seeds were used at the $0.2 \%$ level of contamination, whereas by the conventional PCR technique, it was possible to detect the TC1507 event in samples with $1 \%$ contamination.
\end{abstract}

Index terms: Fast testing, contamination, specificity, transgenesis.

\section{RESUMO}

Com o crescimento do mercado de transgênicos, fazem-se necessárias metodologias rápidas e economicamente viáveis para detecção de transgenes, tanto para a identificação de contaminação em sementes quanto em grãos. Foram utilizadas sementes de cultivares comerciais de milho GNZ 2004 convencional, VT-Pro (MON89034), Round up Ready - RR (NK603) e Herculex (TC1507). Afim de simular diferentes níveis de contaminação, sementes transgênicas foram misturadas às sementes convencionais, nos níveis de $0,2 \%, 0,4 \%, 1,0 \%$ e $1,6 \%$, para VT-Pro e $0,2 \%, 0,5 \%, 0,8 \%$ e $1,2 \%$, para RR e Herculex. O teste de tiras foi realizado em semente inteira, endosperma e embrião. Para a avaliação da especificidade da técnica na detecção do evento TC1507, por meio da técnica de PCR convencional, foram utilizadas, como controle negativo, sementes do híbrido comercial de milho GNZ 2004 e, como controle positivo, o híbrido de milho $2 \mathrm{~B} 655 \mathrm{Hx}$. Com a finalidade de simular diferentes níveis de contaminação, sementes transgênicas (TC1507) foram misturadas às sementes convencionais, nos níveis de $10 \%, 5 \%, 1 \%, 0,5 \%$ e $0,1 \%$. Sementes de cada amostra foram trituradas e foi realizada a extração do DNA pelo método CTAB 2\%. Utilizando-se a tira imunocromatográfica, foi possível avaliar a expressão de proteínas referente aos eventos VT-Pro, RR e Herculex, quando da utilização de sementes inteiras com níveis de contaminação de $0,2 \%$. Foi possível, pela técnica de PCR convencional, detectar o evento TC1507, em amostras com $1 \%$ de contaminação.

Termos para indexação: Testes rápidos, contaminação, especificidade, transgenia.

(Received in april 18, 2013 and approved in june 6, 2013)

\section{INTRODUCTION}

In 2012, 170.3 million hectares of transgenic crops were grown in the world, with a growth of 10.3 million hectares in relation to the year 2011. The growth scenario in adoption of this technology could not be otherwise in Brazil, which has the second largest area in the world planted to GMOs, behind only the United States. In 2012,
36.6 million hectares of transgenic crops were planted in Brazil, with growth of $21 \%$ in relation to 2011 , confirming its place in the ranking of countries that most use the technology of genetically modified organisms (JAMES, 2012). Of the 36.6 million hectares of GMO crops in Brazil, 12.2 million were planted to GMO maize, which corresponded to $76.3 \%$ of the entire area planted to maize in the country(CELERES, 2013). ${ }^{1}$ Universidade Federal de Lavras/UFLA - Departamento de Biologia/DBI - Cx. P. 3037 - 37200-000 - Lavras - MG - Brasil - nacantelmo@hotmail.com
${ }^{2}$ Universidade Federal de Lavras/UFLA - Departamento de Agricultura/DAG - Lavras - MG - Brasil

${ }^{3}$ Universidade Federal de Lavras/UFLA - Lavras - MG - Brasil 
In addition to the increase in the area planted to transgenic crops in Brazil, it is also possible to observe the increasing investment of seed companies, with a greater offering of new transgenic cultivars on the market. Of the 479 maize cultivars available on the market, 216 are transgenic and, of these, 87 transgenic cultivars are being introduced on the market in the 2012/2013 crop season (CRUZ; QUEIROZ; FILHO, 2012).

With the growth in the transgenic market, the development of fast and economically viable methodologies is necessary for undertaking tests for detection of transgenes, both for identification of contamination in seeds and in grain for purposes of commercialization. Techniques that have been most used for diagnosis of the presence of transgenes are immunocromatography, which consists of a simple methodology that does not require specific devices and specialized labor, and PCR, which identifies the presence of the exogenous gene in the plant genome, and is widely practiced throughout the world.

The immunochromatographic strip test is an indirect method of detection because, by means of it, the protein produced by the gene and not the gene in itself is identified, and it is also a test in which generally the presence or absence of this protein is identified.

Detection of the protein arising from the genetic transformation through the use of the immunochromatographic strip is based on a complex of antibodies attached to a strip which are able to recognize this protein. The strip has specific antibodies for the protein, and they are linked to a colored reagent and incorporated in it. This antibody-stain complex then bonds to the target proteins. When the strip comes in contact with the extract that contains the protein, a protein-antibody complex is formed. This colored complex flows by capillarity through the strip, which has two capture zones, one specifically for the target protein and the other specifically for the detection antibody. The detection antibody that does not bond to the protein continues flowing toward the upper part of the strip. The presence of only one line, the control line, in the membrane indicates a negative result, while the appearance of two lines indicates that the sample is positive. In this test, the result is observed rapidly, within 5 to 10 minutes (NASCIMENTO et al., 2012).

The strip test has advantages, as long as the factors that may interfere in its result are considered, like the level of protein expression in seeds and grain. In maize, the seed tissues have different levels of ploidy. The embryo is $2 \mathrm{n}$, with half derived from the father and half from the mother; the endosperm is $3 n$, in which $2 n$ is derived from the mother and $1 \mathrm{n}$ from the father; and the seed coat is $2 \mathrm{n}$, maternal tissue derived from the ovule. Thus, the level of expression of these proteins may be affected by the parent in which the gene was inserted and may, consequently, have an effect on detection of the event (INTERNATIONAL SEED TESTINGASSOCIATION - ISTA, 2009).

Nevertheless, tests based on proteins are not recommended in cases in which the protein, for some reason, is not being expressed in the plant tissue but the exogenous gene is present in its genome. In these cases in which there is the need for directly analyzing the inserted gene, PCR has been the technique most used among all the DNA-based techniques (MARMIROLI et al., 2008).

GMO analysis by means of the PCR technique requires the presence of at least two pairs of primers - one that identifies a constitutive gene of the species and another that identifies the specific gene introduced by the genetic transformation (ELENIS et al., 2008). Endogenous control allows one to control the efficiency of the reaction; when this is amplified, there is confirmation that the reaction is occurring correctly. The specific primer of the event indicates the presence of the transgenic gene in the genome under analysis. In conventional PCR, the presence of the gene is analyzed quantitatively by means of its presence or absence (GRYSON, 2010), just as in the immunochromatographic strip.

The most important thing when using a new primer in the laboratory routine is knowledge of its sensitivity and knowing if it meets the desired standards. Taking into consideration the Brazilian legislation in effect for grain, the primer must be able to identify at least $1 \%$ transgenic contamination in conventional material because the food label has this percentage as a limit for identification of products that contain traces of transgenic material.

This study was performed for the purpose of evaluating detection of protein expression of the VT-Pro event in maize grain lots containing different levels of contamination for the RR and Herculex events in the endosperm, in the embryo and in the whole seed, e and verifying which tissue is most recommended for performing the immunochromatographic strip test. The purpose was also to verify the sensitivity of the primer for identification of the TC1507 event in maize seeds, at different levels of contamination, using conventional PCR.

\section{MATERIAL AND METHODS}

\section{Immunochromatographic strip test (lateral flow membrane strip test)}

The study was conducted in the Central Seed Laboratory of the Universidade Federal de Lavras (Federal 
University of Lavras) in Lavras, MG, duly qualified in accordance with the requirements of NBR ISO/IEC 17025:2005 and licensed in the MAPA for analysis of transgenic seeds. Seeds from commercial conventional GNZ 2004, and transgenic VT-Pro (MON89034), Roundup Ready- RR (NK603) and Herculex (TC1507) maize cultivars were used. For the purpose of simulating different levels of contamination, transgenic seeds (VT-Pro, RR and Herculex) were mixed with conventional seeds at the levels of $0.2 \%, 0.4 \%, 1.0 \%$ and $1.6 \%$, for VT-Pro and $0.2 \%, 0.5 \%$, $0.8 \%$ and $1.2 \%$ for RR and Herculex. These proportions were defined from the specifications of the Envirologix ${ }^{\circledR}$ brand commercial kit, with detection limit of $1.0 \%$ for the VT-Pro event and $0.5 \%$ for the RR and Herculex events.

Before undertaking the strip test, seed tissues were separated so as to verify the level of expression of the proteins in the tissues. The endosperm and the embryo of the maize seeds were separated after being soaked in water for 5 hours. The test was performed in the whole seed, endosperm and embryo.

The test was conducted following the methodology described by the manufacturer. Five hundred seeds ground for 60 seconds were used. To the ground maize was added $1.5 \mathrm{x}$ its weight in water, followed by shaking of the sample. From the supernatant, $0.5 \mathrm{~mL}$ was pipetted, which was added to the reaction tube in which the strip was inserted. After 10 minutes, the results were analyzed. For each event, transgenic seeds were used as positive control and conventional seeds as negative control, which were the same seeds used to simulate the levels of contamination.

\section{PCR multiplex}

For evaluation of the specificity of the technique in detection of the TC1507 event, with the commercial name of Herculex, from the Bayer Cropscience company, seeds of the commercial maize hybrid GNZ 2004 were used as negative control, and seeds of the maize hybrid 2B655Hx, from the Dow Agroscience company, were used as positive control, these being the same seeds as used in the strip test. For the purpose of simulating different levels of contamination, transgenic seeds (TC1507) were mixed with conventional seeds at the levels of $\operatorname{lin} 10(10 \%), 1$ in 20 $(5 \%), 1$ in $100(1 \%), 1$ in $200(0.5 \%)$ and 1 in $1000(0.1 \%)$. These limits were based on the study conducted by Lee et al. (2004) from which were taken the sequences of the primers used. Seeds from each sample were ground up in a cooled mill and then DNA extraction was performed.

For extraction, $620 \mu \mathrm{L}$ of the extraction buffer CTAB 2\% (CTAB 2\%; 1 M Tris- $\mathrm{HCl}$ pH 7.5; 0.5 mM 104 of EDTA $\mathrm{pH} 8.0 ; 5 \mathrm{M} \mathrm{NaCl}$ ) was added to $50 \mathrm{mg}$ of the macerated sample, with the addition of $2 \%$ of $\beta$ mercaptoethanol, and this was incubated at $65^{\circ} \mathrm{C}$ for 60 minutes. At the end of this period, $600 \mu \mathrm{L}$ of chloroform isoamyl alcohol (24:1) mixture was added, which was lightly shaken for 5 minutes to obtain an emulsion, which was afterwards centrifuged at 14,000 rpm for 10 minutes. The supernatant was transferred to a new tube and the previous procedure was repeated. Then, chilled isopropanol was added in the proportion of $1: 1$ and this was centrifuged at 14,000 rpm for 6 minutes and then washed twice with $70 \%$ ethanol and once with $95 \%$ ethanol. After drying at ambient temperature, the DNA was re-suspended in $50 \mu \mathrm{L}$ of ultrapure water $\mathrm{pH} 8.0$ (FERREIRA; GRATTAPAGLIA MODIFICADO, 1998). At the end of extraction, $2 \mu \mathrm{L}$ of RNAse was added, followed by incubation at $37^{\circ} \mathrm{C}$ for thirty minutes. Quantification of DNA was evaluated by the absorbance measurement at $260 / 280 \mathrm{~nm}$ in a spectrophotometer (NanoVue-GE Healthcare) and in $0.8 \%$ agarose gel.

For qualitative detection of the transgenic event, PCR was performed using specific primers for the TC1507 event (LEE et al., 2004) and for the zein gene as endogenous control (NASCIMENTO et al., 2012), as may be observed in table 1 .

The PCR reactions consisted of $100 \mathrm{ng}$ of DNA, 0.2 $\mu \mathrm{M}$ of each primer, $0.2 \mu \mathrm{M}$ of dNTP, $50 \mathrm{mM} \mathrm{MgCl}^{2}$ and 2.5 $\mathrm{U}$ of the Taq polymerase enzyme, in a total volume of 25 $\mu \mathrm{L}$. Amplifications were performed with an initial denaturation stage of $95{ }^{\circ} \mathrm{C}$ for 5 minutes, followed by 5 cycles of $62{ }^{\circ} \mathrm{C}$ for 20 seconds, with decrease of $1{ }^{\circ} \mathrm{C}$ per cycle and $72{ }^{\circ} \mathrm{C}$ for 30 seconds; 30 cycles of $59^{\circ} \mathrm{C}$ for 20 seconds and $72{ }^{\circ} \mathrm{C}$ for 30 seconds, in addition to a final stage of $72^{\circ} \mathrm{C}$ for 5 minutes.

Table 1 - Listing of the primers used in the PCR system.

\begin{tabular}{|c|c|c|c|}
\hline Primer & Name & Sequence & Pairs of bases \\
\hline \multirow{2}{*}{ Zeín } & Zeí 1-5 & CCT CAG TCG CAC ATA TCT ACT ATA CT & \multirow{2}{*}{508} \\
\hline & Zeí 1-3' & CTA GAA TGC AGC ACC AAC AAA & \\
\hline \multirow{2}{*}{ Herculex } & TC-F195 & CTG CCT TCA TAC GCT ATT TAT TTG C & \multirow{2}{*}{251} \\
\hline & TC-R445 & GGA ACA AAC TCA GAC AAC AGG AAA C & \\
\hline
\end{tabular}

Ciênc. agrotec., Lavras, v. 37, n. 5, p. 404-409, set./out., 2013 
The pair of primers used for identification of the TC1507 event (TC-F195 and TC-R445) is annealed in the region of the ubiquitin promoter (MubG1) and of the gene CrylF based on the sequence bank (Accessions in the GeneBank: U29159 and M73254) (LEE et al., 2004).

\section{RESULTS AND DISCUSSION}

\section{Immunochromatographic strip test (lateral flow membrane strip test)}

The expression of the protein for the MON89034 event at the $1 \%$ level of detection, the value recommended by the manufacturer, failed to be observed only in the embryo. At the time of use of embryos, protein expression was observed in maize seed lots containing $1.6 \%$ contamination (Table 2 ). When whole seeds were used, expression of the protein was detected at all levels of contamination. Thus, it may be inferred that it is possible to detect the expression of proteins related to this gene at levels lower than those suggested by the company. It may also be verified that the transgene was inserted in the female parent, seeing as how the combination of the quantity of proteins produced by the embryo and by the endosperm in the whole seed was necessary for there to be detection of the event at levels below that suggested by the company, and that detection in the embryo was only possible in a quantity of contamination greater than that recommended by the company.

Table 2 - Result of the immunochromatographic strip test of the protein Cry2Ab - MON89034 (VT-Pro) event.

\begin{tabular}{ccccc}
\hline \multirow{2}{*}{ Material } & \multicolumn{5}{c}{ Level of contamination (\%) } \\
\cline { 2 - 5 } & 0.2 & 0.4 & $1.0^{*}$ & 1.6 \\
\hline Endosperm & - & - & + & + \\
Embryo & - & - & - & + \\
Whole seed & + & + & + & +
\end{tabular}

*Detection limit for the event, according to technical specifications of the kit.

The results of detection of expression of proteins corresponding to the TC1507 and NK603 events were similar to each other, with the exception of absence of expression of the protein at the $0.8 \%$ and $1.2 \%$ levels of contamination, in the endosperm, for the TC1507 event (Table 3). For the NK603 event, as of the $0.8 \%$ level of contamination, expression of the protein was observed in all the materials (Table 4).

By means of the results obtained, it may be inferred that the transgene was inserted in the male parent since the lowest expression of proteins was observed in the endosperm, with the need for increasing the level of contamination for detection of the protein since the endosperm has $1 \mathrm{n}$ from the male parent and $2 \mathrm{n}$ from the female parent.

Table 3 - Result of the immunochromatographic strip test of the protein Cry1F - TC1507 (Herculex) Event.

\begin{tabular}{ccccc}
\hline \multirow{2}{*}{ Material } & \multicolumn{4}{c}{ Level of contamination (\%) } \\
\cline { 2 - 5 } & 0.2 & $0.5^{*}$ & 0.8 & 1.2 \\
\hline Endosperm & - & - & - & - \\
Embryo & + & + & + & + \\
Whole seed & + & + & + & + \\
\hline
\end{tabular}

*Detection limit for the event, according to technical specifications of the kit.

Table 4 - Result of the immunochromatographic strip test of the protein CP4EPSPS - NK603 (Roundup Ready) event.

\begin{tabular}{ccccc}
\hline \multirow{2}{*}{ Material } & \multicolumn{4}{c}{ Level of contamination (\%) } \\
\cline { 2 - 5 } & 0.2 & $0.5^{*}$ & 0.8 & 1.2 \\
\hline Endosperm & - & - & + & + \\
Embryo & + & + & + & + \\
Whole seed & + & + & + & + \\
\hline
\end{tabular}

* Detection limit for the event, according to technical specifications of the kit.

In both events, even in lots with the lowest level of contamination of $0.2 \%$, detection of expression of the proteins was possible when whole seeds were used. Probably companies adopt the levels of detection indicated in the kit for greater security, in some way avoiding false negative results.

The level of detection of proteins obtained in this study at contamination levels of up to $1 \%$ corroborates et al., 2012; CUNHA et al., 2005; BULCKE et al., 2007; KUMAR et al., 2010; KUMAR, 2012). This shows the efficiency and repeatability of the results, even when using different transgenic events and crops. Thus, the strip test represents a useful tool for identification of a broad range of proteins in various crops (BULCKE et al., 2007).

\section{PCR multiplex}

Before the reactions, tests were carried out to identify the best concentration of DNA in the reaction. Three concentrations were tested: 10, 50 and $100 \mathrm{ng}$ of DNA. As of $50 \mathrm{ng}$, amplification occurred; however, it was seen more clearly at the concentration of $100 \mathrm{ng}$. 
In all the samples analyzed, amplification of the endogenous control, (zein), occurred, indicating the efficiency of the reaction. Among the samples evaluated, only as of $1 \%$ contamination was it possible to observe a specific band of the primer for the TC1507 event (Figure 1). Lee et al. (2004), using the same primer, were able to observe the presence of the event, even in samples with a very low percentage of contamination, as, for example, $0.01 \%$. The difference among the results found may be explained by the large number of variables involved in the process, with DNA extraction being considered as a critical step during the PCR process (MARMIROLI et al., 2008) because it directly affects its quality.

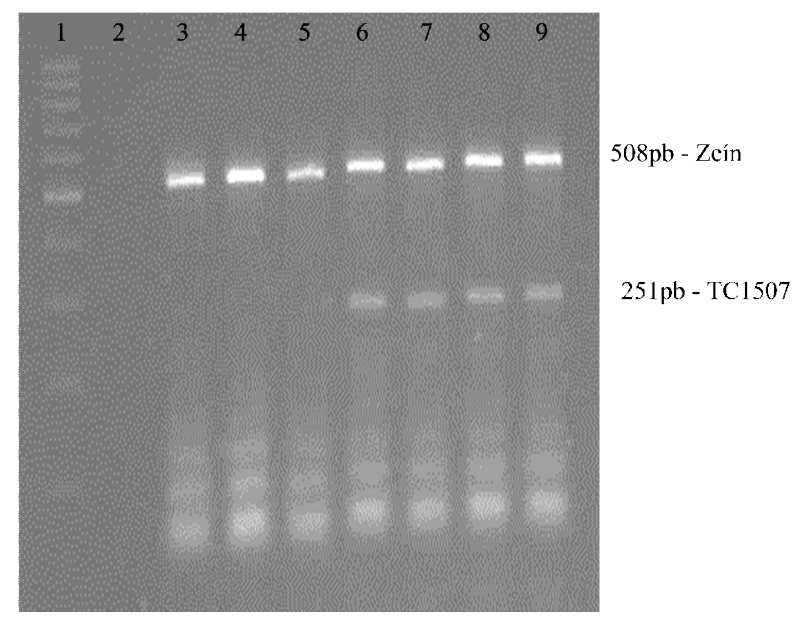

Figure 1 - Result of PCR sensitivity for the TC1507 event. Lines 1-9: $100 \mathrm{pb}$ DNA pattern, negative control, conventional maize sample, $0.1 \%, 0.5 \%, 1.0 \%, 5.0 \%$ and $10.0 \%$ contamination with TC1507 transgenic maize and TC1507 sample.

The DNA analyzed was extracted from seeds, which are plant structures rich in carbohydrates, lipids and proteins, which often hinder DNA isolation, requiring a greater number of washings with the organic solvent, chloroform isoamyl alcohol. These washings lead to reduction in the quantity and quality of the DNA because part of these molecules do not separate from other organic compounds, and are consequently discarded (NASCIMENTO et al., 2012), and there may also be contamination of it by phenolic compounds. Therefore, the quantification and identification of GMOs by means of the PCR technique directly depend on the quality and quantity of the DNA used (GRYSON, 2010).

In spite of the real time PCR technique having a higher cost, its sensitivity and speed are much greater when compared to those of conventional PCR (WANG et al., 2012). For tests that require more precision, real time PCR is recommended over conventional PCR.

The ideal situation in respect to transgenic identification markers is that they be as sensitive as possible because in other countries there are stricter contamination standards, as in countries of the European Union, where the standard is $0.9 \%$. In this case, more precise detection methods are necessary and that has an impact on Brazilian products when they are exported to countries that use stricter limits. The ideal situation would be the use of globalized standards so as to facilitate import and export transactions.

New GMO detection techniques have been described and various techniques are still under development. The use of new techniques in laboratory routines depends on many factors, such as cost and adaptability to these new techniques (QUERCI et al., 2010; ELSANHOTY; RAMADAN; JANY, 2011). For that reason, most laboratories continue using the conventional PCR method (QUERCI et al., 2010).

The immunochromatographic strip test proved to be practical, rapid and easily handled, thus facilitating its routine use, allowing higher speed in decision-making when compared to the PCR test (CUNHA et al., 2005; PÁDUA et al., 2012). For this reason, this test has been successfully used throughout the world (STAVE, 2002). Conventional PCR is a widely disseminated technique in various areas of science, providing precise and reliable analysis for detection of transgenic plants; however, since it is a sensitive test which involves various steps, it requires greater control of quality, specialized labor and specific equipment. It is a test that is not easily standardized, which may lead to low repeatability due to contaminations and differences of calibrations, making it difficult for routine use. However, it may be an important tool in the case of re-tests, helping in decision making (CUNHA et al., 2005). In addition, in the present study, the strip test identified the presence of transgenics in samples with lower levels of contamination, which, added to the other advantages, makes the strip test an important test in identification of transgenics.

\section{CONCLUSIONS}

Regardless of the event analyzed by the immunochromatographic strip test and the level of contamination tested, the best tissue for detection of the event was the whole seed.

It is possible to evaluate the expression of proteins referring to the VT-Pro, RR and Herculex events when whole seeds are used with levels of contamination as of $0.2 \%$. 
It is possible by the PCR technique to detect the TC1507 event in samples with at least $1 \%$ contamination.

\section{REFERENCES}

BULCKE, M. V. et al. Detection of genetically modified plant products by protein strip testing: an evaluation of real-life samples. European Food Research and Technology, Berlim, v.225, n.1, p.49-57,Apr, 2007.

CELERES. $2^{\circ}$ acompanhamento de adoção da biotecnologia agrícola para a safra 2012/13. Available at: $<$ http:// celeres.com.br/wordpress/wpcontent/uploads/2012/12/ RelBiotecBrasil_1202_por.pdf $>$. Accessed on May 21, 2013.

CRUZ, J.C.; QUEIROZ, L.R.; FILHO, I.A. P. Milho-

Cultivares para 2012/2013. Available at: $<$ http:// www.cnpms.embrapa.br/milho/cultivares/>. Accessed on May21, 2013.

CUNHA, C. S. M. et al. Comparação de métodos na detecção de sementes de soja geneticamente modificada resistente ao glifosato. Revista Brasileira de Sementes, Londrina, v.27, n.1, p.167-175, jun, 2005.

ELENIS, D. S. et al. Advances in molecular techniques for the detection and quantification of genetically modified organisms. Analytical and Bioanalytical Chemistry, Heidelberg, v.392, p.347354, Feb, 2008.

FERREIRA, M.E.; GRATTAPAGLIA, D. Introdução ao uso de marcadores moleculares em análise genética. $3 \mathrm{ed}$. Brasília:EMBRAPA/CENARGEN, 1998, 220p.

GRYSON, N. Effect of food processing on plant DNA degradation and PCR-based GMO analysis: a review. Analytical and Bioanalytical Chemistry, Heidelberg, v.396, n.6, p.2003-2022, Dec., 2010.

\section{INTERNATIONALSEED TESTING ASSOCIATION-} ISTA. Position paper on ISTA's view regarding the units for the reporting of quantitative results on presence of seeds with specified traits in conventional seed lots. Switzerland, p.4, 2009.

JAMES, C. Global Status of Commercialized Biotech/ GM Crops: 2012. ISAAA Brief 44-2012. Available at: $<$ http://www.isaaa.org/resources/publications/briefs/44/ executivesummary/default.asp $>$. Accessed on May 21, 2013.
KUMAR, R. Development of dipsticks for simultaneous detection of vip3A and Cryl Ab/Cry1 Ac transgenic proteins. Journal of AOAC International, Ottawa, v.95, n.4, p. 1131-1137, Jul., 2012.

KUMAR, R. et al. Development of nanocolloidal gold based immunochromatographic assay for rapid detection of transgenic vegetative insecticidal protein in genetically modified crops. Food Chemistry, Reading, v.122, n.4, p.1298-1303, Oct., 2010.

LEE, S. H. et al. Qualitative PCR method for detection of genetically modified maize lines NK603 and TC1507.

Agricultural Chemistry \& Biotechnology, Suwon, v.47, n.4, p. 185-188, Dec., 2004.

MARMIROLI, N. et al. Methods for detection of GMOs in food and feed. Analytical and Bioanalytical Chemistry, Heidelberg, v.392, n.3, p.369-384, Oct., 2008.

NASCIMENTO, V. E. et al. Detection limits of the strip test and PCR for genetically modified corn in Brazil. Genetics and Molecular Research, Ribeirão Preto, v.11, n.3, p.2497-2505, jun, 2012.

PÁDUA, G. P. et al. Detecção de presença adventícia de semente geneticamente modificada em lotes de soja não transgênica. Revista Brasileira de Sementes, Londrina, v.34, n.4, p.573-579, dec, 2012.

QUERCI, M. et al. New approaches in GMO detection. Analytical and Bioanalytical Chemistry, Heidelberg, v.396, n.6, p.1991-2002, mar, 2010.

SANHOTY, R. M.; RAMADAN, M. F.; JANY, K. D. DNA extraction methods for detecting genetically modified foods: A comparative study. Food Chemistry, Reading, v.126, n.4, p.1883-1889, jun, 2011.

STAVE, J.W. Protein immunoassay methods for detection of biotech crops: Applications, limitations, and practical considerations. Journal of AOAC

International, Ottawa, n.85, n.3, may, 2002.

WANG, X. et al. Comparison of three DNA extraction methods for feed products and four amplification methods for the 52 -junction fragment of roundup ready soybean. Journal of Agriculture Food Chemistry, Washington, v.60, n.18, p.4586-4595, may, 2012. 